\title{
Physico-Chemical, Functional and Rheological Properties of Proteins from Pinkperch (Nemipterus japonicus) Meat: Effect of Freezing and Frozen Storage
}

\author{
K. Rathnakumar ${ }^{1,2 *}$ \\ ${ }^{1}$ Department of Fish Processing Technology, University of Agricultural Sciences, College of \\ Fisheries, Mangalore - 575 002, India \\ ${ }^{2}$ Department of Fish Process Engineering, College of Fisheries Engineering, Tamil Nadu \\ Fisheries University, Nagapattinam - 611 001, India \\ *Corresponding author
}

\section{A B S T R A C T}

\begin{tabular}{|l|}
\hline Ke y w or d s \\
$\begin{array}{l}\text { Pinkperch } \\
\text { (Nemipterus } \\
\text { japonicas), Frozen } \\
\text { storage }\end{array}$ \\
\hline Article Info \\
\hline $\begin{array}{l}\text { Accepted: } \\
\text { 26 February } 2018 \\
\text { Available Online: } \\
10 \text { March } 2018\end{array}$ \\
\hline
\end{tabular}

\section{Introduction}

The most important criteria used to determine the usefulness of a food protein is its functional performance in food processing. Apart from their high nutritive value, fish proteins as a whole exhibit excellent functional properties, as manifested by their ability to form visco elastic gels, to bind water, to emulsify fat and oil and to form stable foams (Xiong 1997). For long term preservation of fish and fishery products

\begin{abstract}
The properties of total protein from whole pinkperch (Nemipterus japonicus) meat as affected by freezing and frozen storage at $-20^{\circ} \mathrm{C}$ have been assessed. Three major protein components were indicated by gel filtration profile. The apparent reduced viscosity at zero protein concentration was $0.109 \mathrm{ml} / \mathrm{mg}$. The gel forming ability of the meat was high as indicated by large strain and small strain test. Freezing and frozen storage of pinkperch meat for 300 days reduced the protein solubility and $\mathrm{Ca}^{++}$ATPase activity significantly $(\mathrm{P}<0.05)$. The aggregation reaction was more evident from reduced viscosity measurements at different protein concentrations, gel filtration profile and SDS-PAGE pattern. The emulsion capacity and stability was reduced to $58 \%$ and $38 \%$ respectively by freezing and frozen storage. The gel forming ability decreased with increase in frozen storage period. The dynamic viscoelastic behaviour as a function of frozen storage revealed a loss in elastic structure build up reaction. Setting of pinkperch meat at $30^{\circ} \mathrm{C}$ for $1 \mathrm{hr}$ increased the gel strength and altered the gelation profile.
\end{abstract}

freezing and frozen storage has been the choice of the method of preservation (Sikorski et al., 1976; Shenouda 1980; Matsumoto 1980). The rate of loss in eating quality is very much dependent on species, method of freezing, time and temperature of frozen storage (Kinsella 1982). Textural properties of fish meat are mainly attributed to major protein components viz. myosin, and actomyosin complex (Asghar et al., 1985; Foegeding, 1987; Xiong, 1992). As a consequence of freezing and frozen storage 
these proteins will undergo series of alterations leading to changes in physico chemical and functional properties (Sikorski et al., 1976). It is well documented that conformation of the protein molecules are key to different functional and rheological properties (Mac Donald and Lanier 1991; Hamann 1992; Damodaran, 1994). Surimi is primarily a concentrate of myofibrillar proteins obtained from different fish species after water washing the minced muscle, with added cryoprotectants to ensure a good frozen storage (Tejada 1994). Surimi has been used as raw material for texturised and formulated fish product like sea food analogue and fish sausage. The ability of protein to bind fat is important in sausages, meat replacers and extenders, where the mouthfeel is an important criteria. Textural analysis are important for evaluating gels formed from food materials and are usually used for quality control, comparison purposes and food product development (Ziegler and Foegeding 1990). Fundamental rheological tests provide critical information on time dependent viscoelastic behaviour and the molecular mechanism surrounding the changes in structure when a protein is undergoing gelation (Kinsella 1982; Ziegler and Foegeding 1990). Rheological study includes "small-strain testing" and "large straintesting'. Small strain rheological measurement as a function of temperature is mainly studied with reference to elastic and viscous component. It is fairly well established that large-strain instrumental testings required to correlate with sensory texture which inturn can determine the acceptability of a product (Montejano et al., 1985).

Pinkperch fish a thread fin bream constitutes $5 \%$ of total marine landing in India. The average marine landing of pinkperch fish is around 90,000 MT (CMFRI 1995). The meat of pinkperch has less of fat and high gel forming ability (Holmes et al., 1992) and forms a ideal raw material for the preparation of surimi and gel products like fish sausage and Kamaboko type products. In India few surimi plants have been established recently and using pinkperch fish as a raw material extensively along with other species. Some of the earlier works have been carried out on the changes in the properties of proteins from pinkperch mince during iced frozen storage (Reddy and Srikar 1991; Srikar and Reddy 1991). In the present investigation an attempt has been made to understand the changes in the physico-chemical, functional and rheological behaviour of protein from the whole pinkperch as affected by freezing and frozen storage.

\section{Materials and Methods}

Sodium chloride, phosphate buffer salts (monobasic and dibasic), acetic acid and acetone were obtained from E.merck (India) Ltd. Acrylamide, $\beta$-Mercapto ethanol, bis(acrylamide), sodium dodecyl sulfate, bovine serum albumin, Trizma base, ammonium persulfate and Bromophenol blue were procured from Sigma Chemical Co. Sepharose $6 \mathrm{~B}$ and Blue dextran were purchased from Pharmacia fine chemicals. Refined sun flower oil of sundrop brand was obtained from M/s ITC-AgroTech, Secundrabad, India.

Pinkperch (Nemipterus japonicus) fish caught off Mangalore, west coast of India were brought to the laboratory in iced condition. Fishes were thoroughly washed, packed in polythene bag (4-5 fishes) and air blast frozen at $-35^{\circ} \mathrm{C}$ for $45 \mathrm{~min}$ using a blast freezer of Armfield Ltd., Ringwood Hampshire, England. Frozen samples were stored at $-20^{\circ} \mathrm{C}$ until further use. The frozen samples were drawn at a periodic interval and thawed at $+4^{\circ} \mathrm{C}$ for overnight for further analysis. Moisture, protein, fat and ash content of pinkperch meat were estimated according to the procedures of the AOAC (1984). All of the 
experiments were done in triplicate and the mean values were reported. Non-protein nitrogen (NPN) was determined by the method of Velankar and Govindan (1958) using trichloro-acetic acid precipitation.

\section{Nitrogen solubility index (NSI)}

NSI of fresh pinkperch was carried out with distilled water as solvent. $3 \mathrm{~g}$ of meat homogenised with $20 \mathrm{ml}$ of distilled water at $3000 \mathrm{rpm}$ using Ultratarrax, homogeniser for $30 \mathrm{sec}$. The $\mathrm{pH}$ of slurry was adjusted to desired level (range 2-12) using $0.1 \mathrm{M} \mathrm{HCl}$ $/ \mathrm{NaoH}$. The slurry was homogenised again for $15 \mathrm{sec}$ and centrifuged at $10,000 \times \mathrm{g}$ for $20 \mathrm{~min}$ using IEC B-22 refrigerated centrifuge at $4^{\circ} \mathrm{C}$. Total nitrogen content in supernatant of each sample was determined by Kjeldahl method. The protein extracted $(\mathrm{N} \times 6.25)$ was expressed as $\%$ total protein.

\section{Nitrogen solubility as a function of sodium chloride concentration}

$3 \mathrm{~g}$ of meat with $30 \mathrm{ml}$ of phosphate buffer (0.05 M, pH 7.5) containing, 0.3 M, 0.6 M, 0.8 $\mathrm{M}, 1.0 \mathrm{M}, 1.5 \mathrm{M}$ and $2.0 \mathrm{M}$ sodium chloride respectively was homogenised at $3000 \mathrm{rpm}$ for one min and centrifuged at $10,000 \times \mathrm{g}$ for 20 min. Total nitrogen content in the supernatant was determined by Kjeldahl method. The protein solubilized $(\mathrm{N} \times 6.25)$ was expressed as $\%$ total protein.

\section{Solubility of pinkperch meat in extraction buffer}

Phosphate buffer (0.05 M, pH 7.5) containing 1 $\mathrm{M} \mathrm{NaCl}$ herein after will be referred as extraction buffer (EB). $3 \mathrm{~g}$ of meat was mixed with $25 \mathrm{ml}$ of EB and homogenised at 3000 rpm for 1 min using Ultra-tarrax homogeniser. The slurry was centrifuged at $10,000 \times \mathrm{g}$ for 15 min at $4{ }^{\circ} \mathrm{C}$. Nitrogen content in the supernatant was estimated using Kjeldahl method.

\section{Viscosity}

Viscosity measurements of pinkperch protein solution were made using an ostwald viscometer at $25.0 \pm 1{ }^{\circ} \mathrm{C}$. The flow time for double distilled water and EB were 85 and 90 $\mathrm{sec}$ respectively. Protein solutions of $10 \mathrm{ml}$ were equilibrated to the viscometer bath temperature. The apparent reduced viscosity $\left(\eta_{\text {red }}\right)$ of the protein solutions were obtained from its relative viscosity value according to the procedures of Yang (1961) and Bradbury (1970). The $\eta_{\text {red }}$ values were obtained over the range of protein concentration and a plot of protein concentration $(\mathrm{mg} / \mathrm{ml})$ versus $\eta_{\text {red }}$ were obtained.

\section{$\mathrm{Ca}^{2+}$ ATPase activity}

$\mathrm{Ca}^{2+}$ ATPase activity was measured according to the method of Noguchi and Matsumoto (1970). About $1 \mathrm{~g}$ of meat was homogenised in $10 \mathrm{ml}$ of $50 \mathrm{mM}$ Tris- $\mathrm{HCl}$ buffer $(\mathrm{pH} \mathrm{8.0)}$. Homogenate was centrifuged at $8000 \times \mathrm{g}$ for $15 \mathrm{~min}$ at $4^{\circ} \mathrm{C}$. The supernatant thus obtained was used as source of enzyme. $0.4 \mathrm{ml}$ of enzyme extract was added to the reaction mixture consisting of $0.06 \mathrm{ml}$ of ATP (50 $\mathrm{mM}$ ) solution, $0.4 \mathrm{ml}$ of $\mathrm{CaCl}_{2}(100 \mathrm{mM}), 2.0$ $\mathrm{ml}$ of Tris- $\mathrm{HCl}$ buffer $(50 \mathrm{mM}, \mathrm{pH} 8.0)$ and incubated for $5 \mathrm{~min}$ at $27^{\circ} \mathrm{C}$. The reaction was stopped by adding $2 \mathrm{ml}$ of TCA. Liberated inorganic phosphorus was determined by the method of Taussky and Shorr (1952).

\section{Gel filtration}

Gel filtration of total protein extracted from meat samples were carried out using sepharose-6B gel packed in a column of $1.5 \times$ $80 \mathrm{~cm}$ (dia $\times$ height) using EB as eluant. The total bed volume of the column was $135 \mathrm{ml}$ and void volume (Vo) determined using blue dextran was found to be $44.0 \mathrm{ml}$. The protein concentration used for loading the column was $17-18 \mathrm{mg}$. The flow rate was adjusted to 30 
$\mathrm{ml} / \mathrm{hr}$ and fractions of $3 \mathrm{ml}$ were collected manually in tubes. The concentrations of the fractions were measured at $280 \mathrm{~nm}$ using a Bausch and Lomb, Spectronic -21, Spectrophotometer. A plot of absorbance versus elution volume was obtained for each run.

\section{Emulsion capacity (EC)}

EC of total proteins from meat was determined by the method of Swift et al., (1961). $25 \mathrm{~g}$ of meat was homogenised with $100 \mathrm{ml}$ of chilled EB for $2 \mathrm{~min}$. The slurry was kept in refrigerator for $15 \mathrm{~min}$ to get equilibrated. To $12.5 \mathrm{~g}$ of slurry $37.5 \mathrm{ml}$ of chilled EB and $50 \mathrm{ml}$ of refined oil were added. First it was homogenised at $9000 \mathrm{rpm}$ for 5-10 sec then homogenised at high speed $(23,000 \mathrm{rpm})$ with continuous addition of oil at the rate of 0.5 to $0.6 \mathrm{ml} / \mathrm{sec}$ was carried out until phase inversion occurred. The volume of oil consumed till the collapse of emulsion was recorded and the EC was expressed as milli litres of oil per mg protein.

\section{Emulsion stability (ES)}

ES of meat was determined according to the method of Paulson and Tung (1988). $10 \mathrm{~g}$ of meat was homogenised with $100 \mathrm{ml}$ of $\mathrm{EB}$ at $3000 \mathrm{rpm}$ for $2 \mathrm{~min}$ and centrifuged at $8000 \times$ $\mathrm{g}$ for $15 \mathrm{~min}$. To $10 \mathrm{ml}$ of supernatant $10 \mathrm{ml}$ of oil was added and homogenised at $8000 \mathrm{rpm}$ for $1 \mathrm{~min} .1 \mathrm{ml}$ of homogenate was mixed with $9 \mathrm{ml}$ of EB containing $0.1 \%$ SDS and the absorbance was measured at $500 \mathrm{~nm}$. ES was expressed as time taken to reach half of the initial reading of absorbance at $500 \mathrm{~nm}$.

\section{Water absorption capacity (WAC)}

Meat sample was freeze-dried using Edwards, super modulyo, U.K. WAC of freeze-dried material was determined by the method of Sosulski (1962). $0.3 \mathrm{~g}$ of freeze dried sample was mixed well with $5 \mathrm{ml}$ of water in a preweighed centrifugation tube and allowed to stand for $30 \mathrm{~min}$. Then centrifuged at $7000 \times \mathrm{g}$ for $10 \mathrm{~min}$, the excess water released from sample was decanted by inverting the tubes at $45^{\circ}$ angle for $30 \mathrm{~min}$ at $50^{\circ} \mathrm{C}$. The tubes were weighed and WAC was expressed as grams of water per grams of dried material.

\section{Preparation of gel}

About $400 \mathrm{~g}$ of separated meat was ground with $2.5 \% \mathrm{NaCl}$ using pre-chilled pestle and mortar for $10 \mathrm{~min}$ at $4^{\circ}-5^{\circ} \mathrm{C}$. The viscous paste thus obtained was stuffed into Krehlon casings (40 mm thickness) of $3.0 \times 20 \mathrm{~cm}$ (dia $\times$ length) using hand stuffer and sealed with aluminum wire. One batch of stuffed casings were subjected to heat processing immediately at $90^{\circ} \mathrm{C} \pm 2{ }^{\circ} \mathrm{C}$ for $45 \mathrm{~min}$ and then cooled in chilled water for $15 \mathrm{~min}$. The other batch of stuffed casings were incubated at room temperature $\left(28^{\circ} \pm 2^{\circ} \mathrm{C}\right)$ for $1 \mathrm{hr}$ to allow for setting process and then heat processed as in the case of unset meat. The gels obtained from both set and unset meat were kept at $5^{\circ} \mathrm{C}$ overnight and then used for gel strength measurements.

\section{Gel strength}

Gel strength of the gel prepared as above was measured using Okado gellometer by the method as described by Suzuki (1981). A 25 $\mathrm{mm}$ thick piece of gel was placed in under the plunger of gellometer. The pressure on the gel piece was applied by continuous running water collected into a graduated beaker placed over the plunger. The flow rate of water was adjusted to a constant volume. The movement of stylus on the kymograph was recorded and the gel strength was measured by calculating the area of triangle under the graph. The gel strength was measured in triplicate. $\mathrm{F}$ factor was calculated by measuring the volume of water collected for a known time and the 
distance $(\mathrm{cm})$ moved by the needle in Kymograph. $\mathrm{F}$ factor is calculated as -

$\mathrm{F}=\frac{\text { Vol. of water run down in unit time }(\mathrm{ml})}{\text { Distance moved by down in unit time }(\mathrm{cm})}$

The following formula was used to calculate the strength of the gel (G.S).

$\mathrm{GS}=1 / 2 \mathrm{~F} \times \mathrm{A} \times \mathrm{B}$ g.cm.

$\mathrm{A}=$ The base of triangle in $\mathrm{cm}$.

$\mathrm{B}=$ Height of the triangle in $\mathrm{cm}$.

\section{Dynamic visco - elasticity measurement}

The visco-elastic properties of meat in the range of temperature $30^{\circ}-90^{\circ} \mathrm{C}$ was carried out using Carri Med Controlled Stress Rheometer (CSR) (Surrey, U.K.) under Oscillation mode. The measuring geometry used was $4 \mathrm{~cm}$ parallel plate and the gap between the peltier plate and measuring system was set at 2000 $\mu \mathrm{m}$. The amplitude of the stress wave was $0.0005 \mathrm{rad}$ with the frequency of $1 \mathrm{~Hz}$. The "In" phase component being storage modulus or elastic component $\left(\mathrm{G}^{\prime}\right)$ and the 'out' phase component is viscous or loss modulus (G'). These two values along with sol-gel transition phase $\left(\tan \delta=G^{\prime \prime} / G^{\prime}\right)$ were recorded continuously by the instrument.

About $4 \mathrm{~g}$ meat was macerated with $2.5 \%$ $\mathrm{NaCl}$ (w/w) using pestle and mortar for a constant time and then placed on to peltier plate for measurement of viscoelastic properties. The rate of heating was $1^{\circ} \mathrm{C}$ per min achieved through the peltier system of the instrument.

\section{Sodium Dodecyl Sulfate Polyacrylamide Gel Electrophoresis: (SDS - PAGE)}

SDS-PAGE was carried out using a slab gel of $10 \times 8 \mathrm{~cm}$ (length $\times$ width) in a slab gel apparatus of Hoofer Pharmacia Biotech. USA.
A discontinuous gel of acrylamide concentration $10 \%(\mathrm{~T})$ and $6.5 \%(\mathrm{~T})$ was used along with TEMED and ammonium persulfate $(0.1 \%)$. A constant current of $2 \mathrm{~mA}$ per well of the gel was supplied using Hoofer Pharmacia Biotech. USA power pack (PS 3000, DC powder supply). The running buffer contained $1.5 \mathrm{M}$ Tris- $\mathrm{HCl}$ buffer and $10 \%$ SDS. After each run, gels were stained in Coomassie blue and destained using $7 \%$ acetic acid (Laemmli, 1970). 2 g of meat was ground well with $2 \mathrm{ml}$ of treatment buffer $(10 \mathrm{ml}$ of treatment buffer contains, $2.5 \mathrm{ml}$ of $4 \mathrm{x}$ tris$\mathrm{HCl}, 4 \mathrm{ml} \mathrm{10 \%}$ SDS, $2.0 \mathrm{ml}$ glycerol, $0.2 \mathrm{ml}$ mercapto ethanol, $0.2 \mathrm{mg}$ bromophenol blue and $1.3 \mathrm{ml} \mathrm{DDW}$ ) and the content was heated in boiling water bath at $100^{\circ} \mathrm{C}$ for $2 \mathrm{~min}$. It was cooled, centrifuged to get a clear supernatant and stored in vials at $-20^{\circ} \mathrm{C}$ for future study. $5 \mu \mathrm{l}$ of clear solution $(5-8 \mu \mathrm{g})$ was loaded onto the gel.

\section{Statistical analysis}

The data obtained were statistically analysed using Karl pearsons linear correlation coefficient (Yamane 1967).

\section{Results and Discussion}

The composition of pinkperch meat indicated a moisture content of $73.84 \%$ and a total protein content of $18.9 \%$ (Table 1). The NPN content of the meat constituted $10 \%$ of total nitrogen. The bottom dwelling fishes like pinkperch are known to have less of NPN content compared to pelagic and shell fishes (Tarr 1958). The fat content of the fish is less than three percent, which can be taken as lean variety fish. The variation in fat content with season of Indian marine fishes is well documented (Sen and Revanker 1972; Gopakumar 1992).

The protein extractability in phosphate buffer, $\mathrm{pH} 7.5,50 \mathrm{mM}$ containing $1 \mathrm{M} \mathrm{NaCl}$ was 
91.2\% (Table 1). The extractability of protein from different fresh fish in high ionic strength buffer varies from $85-95 \%$ of total proteins (Shamasundar and Prakash, 1994a). The extractability in high ionic strength buffer is generally taken as index of denaturation of myofibrillar protein and is monitored during different processing. The high extractability value in the present study indicates the fresh quality of pinkperch. The assay of $\mathrm{Ca}^{2+}$ ATPase activity of fresh meat was $0.684 \mu \mathrm{g}$ $\mathrm{Pi} / \mathrm{mg}$ protein/min. In the present study the assay was carried out in the total protein extract, the involvement of sarcoplasmic ATPase cannot be ruled out. However the ATPase enzyme activity of fresh fish of many species is in the range of 0.182 to $1.8 \mu \mathrm{g}$ $\mathrm{Pi} / \mathrm{mg}$ protein/min (Suzuki 1981; Numakura et al., 1989; Chan et al., 1995). Some of the properties of total protein obtained from fresh pinkperch are also given in Table 1. The results will be discussed along with storage behaviour pattern.

The NSI of fresh pinkperch meat is given in Figure 1A. The NSI was carried out in the $\mathrm{pH}$ range of 2.5 to 11.0 . The minimum solubility was recorded in the region of $\mathrm{pH} 5.0$ to 6.0. The solubility was high in alkaline $\mathrm{pH}$ range than that of acidic range. As the $\mathrm{pH}$ approaches the isoelectric point, the negative and positive charges among protein molecules are equal. Therefore, protein molecules are strongly associated with each other through ionic linkages (Kinsella 1984). Protein has reduced solubility at that $\mathrm{pH}$ because protein water-interaction is replaced by proteinprotein interaction. The usefulness of NSI profile is helpful in deciding the optimum $\mathrm{pH}$ for protein solubility in different processing. Figure 1B depicts the solubility profile of proteins from pinkperch as a function of $\mathrm{NaCl}$ concentration. With an increase in molar concentration more protein could be solublized and a maximum extractability of 91.2\% was recorded at $1 \mathrm{M}$ concentration. At
1.5 and 2.0 $\mathrm{M}$ concentration a reduction in solubility was observed mainly due to salting out phenomenon. As the maximum solubility obtained at $1 \mathrm{M} \mathrm{NaCl}$ the same concentration was used for all further studies.

Solublization of myofibrillar proteins is prerequisite for many functional properties. Figure 2A gives the percentage of protein extracted as a function of frozen storage period. The process of freezing reduced the extractable protein from 91.20\%-57.29\%. Subsequent storage at $-20^{\circ} \mathrm{C}$ showed a gradual decrease and reached the value of $41.62 \%$ at the end of 300 days storage. Similarly the $\mathrm{Ca}^{2+}$ ATPase activity showed a steep fall due to the freezing process and the values increased upto 60 days of storage (Fig. 2B). The rate of decrease in the ATPase activity was gradual upto 270 days of storage and reached a value of $0.109 \mu \mathrm{g} \mathrm{Pi} / \mathrm{mg}$ protein $/ \mathrm{min}$ at the end of 300 days. Both protein extractability and measurement of $\mathrm{Ca}^{2+}$ ATPase activity indicates alteration in the myofibrillar protein as induced by freezing and frozen storage. The alteration in the conformational status in major protein fraction, myosin is by aggregation (Tsuchiya et al., 1980). Such a process of aggregation is mediated by hydrophobic, disulfide and other covalent linkages (Colmenero and Borderias 1983; Matsumoto 1979; Xiong 1997). The increase in ATPase enzyme activity during the initial phase of frozen storage period was attributed to modification of the natural barrier between enzyme and substrate or activator (Briskey and Fukazawa 1971).

The apparent reduced viscosity of total proteins from pinkperch stored for different duration at $-20^{\circ} \mathrm{C}$ is given in Figure $3 \mathrm{~A}$. The apparent reduced viscosity as a function of protein concentration changed with storage period indicating an alteration in the shape of the protein molecule. This was also evident from the slope of the curve obtained for 
different storage period. A derivative graph was obtained by plotting storage period versus $\eta_{\text {red }}$ at $10 \mathrm{mg} / \mathrm{ml}$ protein concentration (Fig. $3 \mathrm{~B})$. There is a progressive reduction in reduced viscosity with increase in storage period. The rate of decrease was maximum in first 100 days of storage, presumably due to formation of aggregates which was further supported by solubility profile as a function of frozen storage period. The decrease in viscosity could be due to protein alterations with the subsequent formation of small size aggregates, which corresponds to proteinprotein interactions (Hermansson, 1979). The formation of aggregates increased in size with increase in frozen storage period and giving rise to a greater loss of extractable protein and a drastic decrease in viscosity (Borderias et al., 1985). The decrease in reduced viscosity with increase in frozen storage period has been reported (Pastoriza et al., 1994; Montecchia et al., 1997).

The gel filtration profile of total protein from fresh pinkperch meat and frozen stored for different duration are given in Figure 4. Total protein from fresh pinkperch had 3 fractions, two major and one minor. Among two major fractions one is high molecular weight component eluting at an elution volume 61.2 $\mathrm{ml}$ and a low molecular weight component eluting at an elution volume of 135.5. The minor peak eluted at $109.7 \mathrm{ml}$ and is intermediary in molecular weight between the two major components. With freezing and frozen storage for different periods, elution pattern of the 3 peaks varied considerably indicating association - dissociation reaction. The dissociative process was more evident in peak II (minor fraction) component where at the end of 300 days of storage, the fraction eluted at the volume of $119.9 \mathrm{ml}$. The concentration of peak I reduced progressively with increase in frozen storage period which was evident from gel filtration profile and SDS-PAGE pattern of the fraction collected
(Fig. 5). Gel filtration profile of proteins from fish carried out by using different gels has been reported (Umemoto and Kanna, 1970; Seki and Arai, 1974; Ohnishi and Rodger, 1980). The elution profile compares well with the present study. Ohnishi and Rodger (1980) obtained the elution sequence of myosin heavy chain, actin and tropomyosin. The results obtained in the present study agree with the above observation. Elution sequence in gel filtration has direct bearing on type of buffer $\mathrm{pH}$ salt concentration used. The gel filtration date suggests the molecular association - dissociation reaction.

The order to understand the association dissociation phenomenon further, SDS-PAGE of total protein from pinkperch stored at $-20^{\circ} \mathrm{C}$ for different duration were carried out. The SDS-PAGE pattern of fresh pinkperch suggests the presence of multiple bands with clear myosin heavy chain at top (Fig. 6).

With increase in frozen storage period there was a progressive reduction in $\mathrm{MHC}$ concentration which could be due to the aggregation process. This result corroborates well with the gelfiltration profile wherein the concentration of peak I is reduced. The SDSPAGE pattern of total proteins obtained from the latter parts of the storage period indicates the dissociative process by increasing number of low molecular weight bands (Fig Lane I). This association - dissociation process of the total protein of pinkperch during storage period may have a bearing on the functional properties.

The EC of total proteins from pinkperch registered a decrease of $53 \%$ from its original value at the end of 300 days of frozen storage (Fig. 7) the reduction in EC value could be attributed to the formation of aggregates during storage. The ES value registered a steep fall in first 30 days of frozen storage and reached the values of $3.35 \mathrm{~min}$ at the end of 300 days of storage (Fig. 7). 
Fig.1A Nitrogen solubility Index of total proteins from fresh pinkperch meat with distilled water as solvent

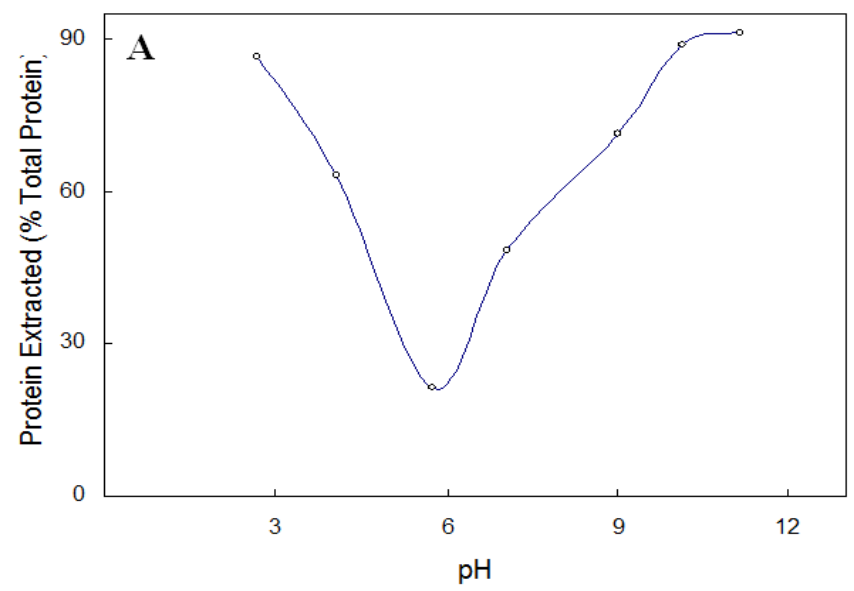

Fig.1B Protein solubility of fresh pinkperch meat as a function of molar concentration of sodium chloride in phosphate buffer (50mM; pH 7.5)

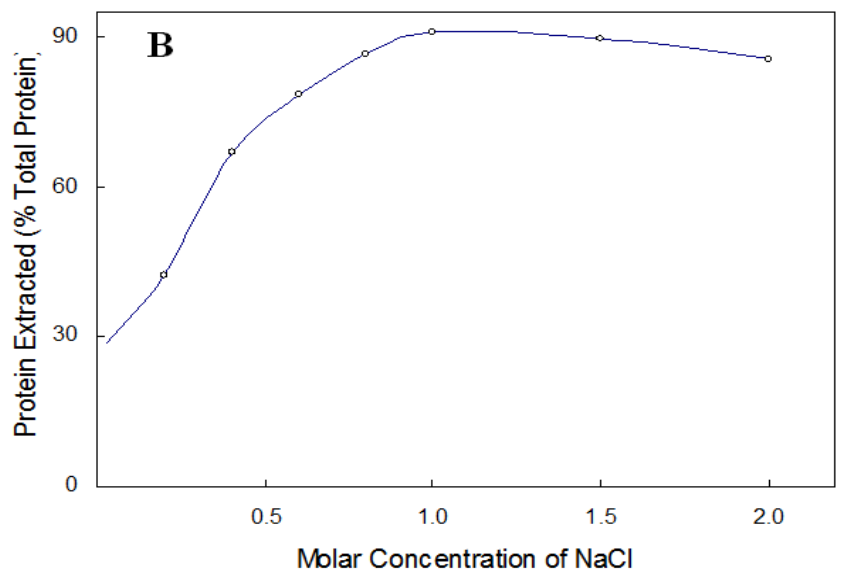

Fig.2A Effect of freezing and frozen storage at $-20^{\circ} \mathrm{C}$, of pinkperch meat on the solubility of total proteins. The solvent used was EB and soluble protein was expressed as \% solubilized of total protein content of meat

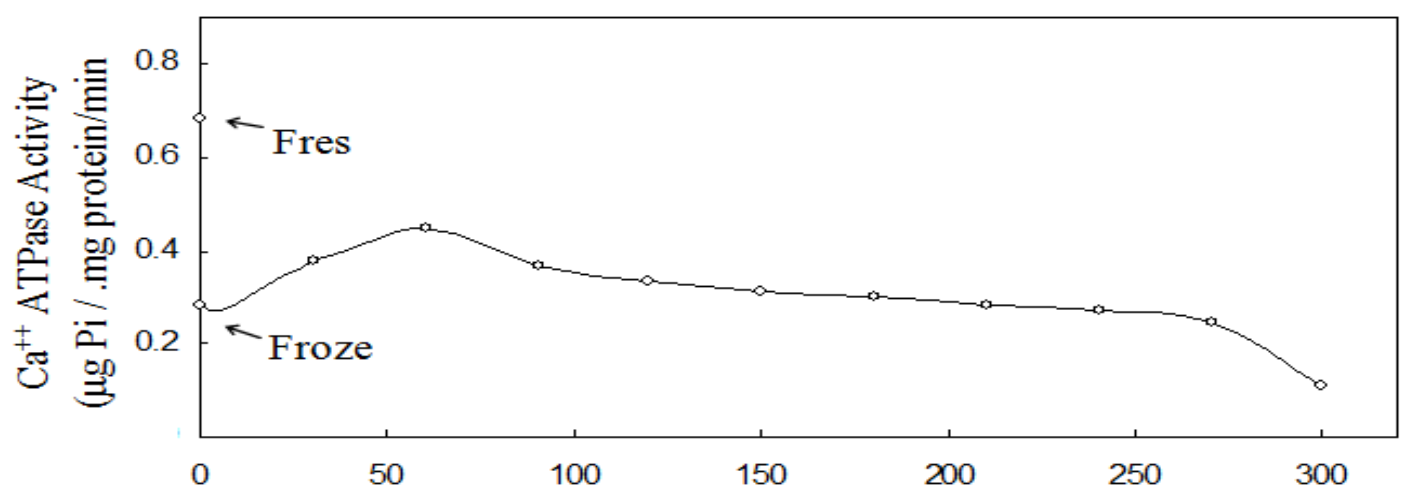


Fig.2B Effect of freezing and frozen storage at $-20^{\circ} \mathrm{C}$, of pinkperch meat on calcium ATPase activity of muscle extract in Tris- $\mathrm{HCl}$ buffer, $\mathrm{pH} 8.0,50 \mathrm{mM}$

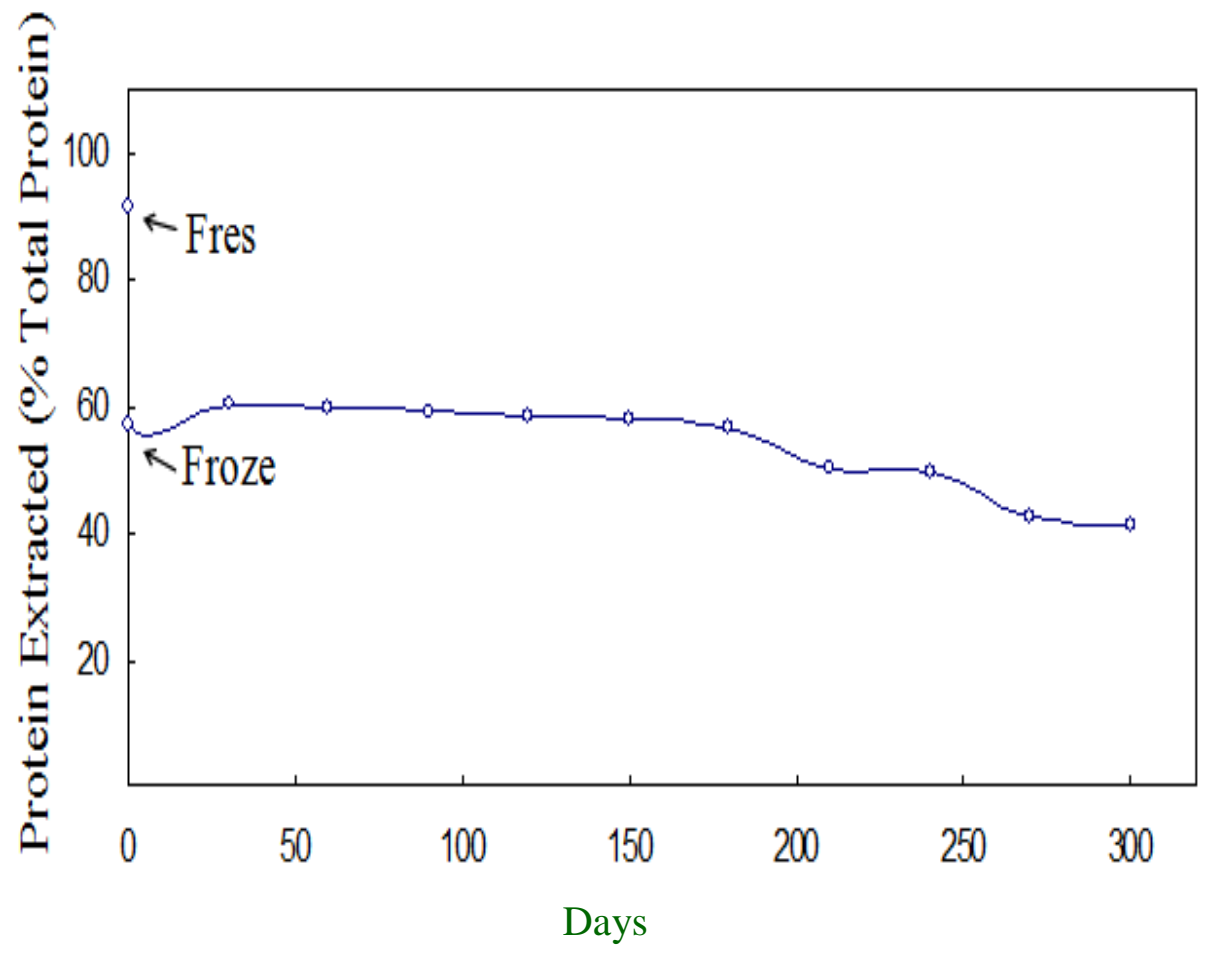

Fig.3A Changes in Non-protein nitrogen content of pinkperch meat as affected by freezing and frozen storage at $-20^{\circ} \mathrm{C}$

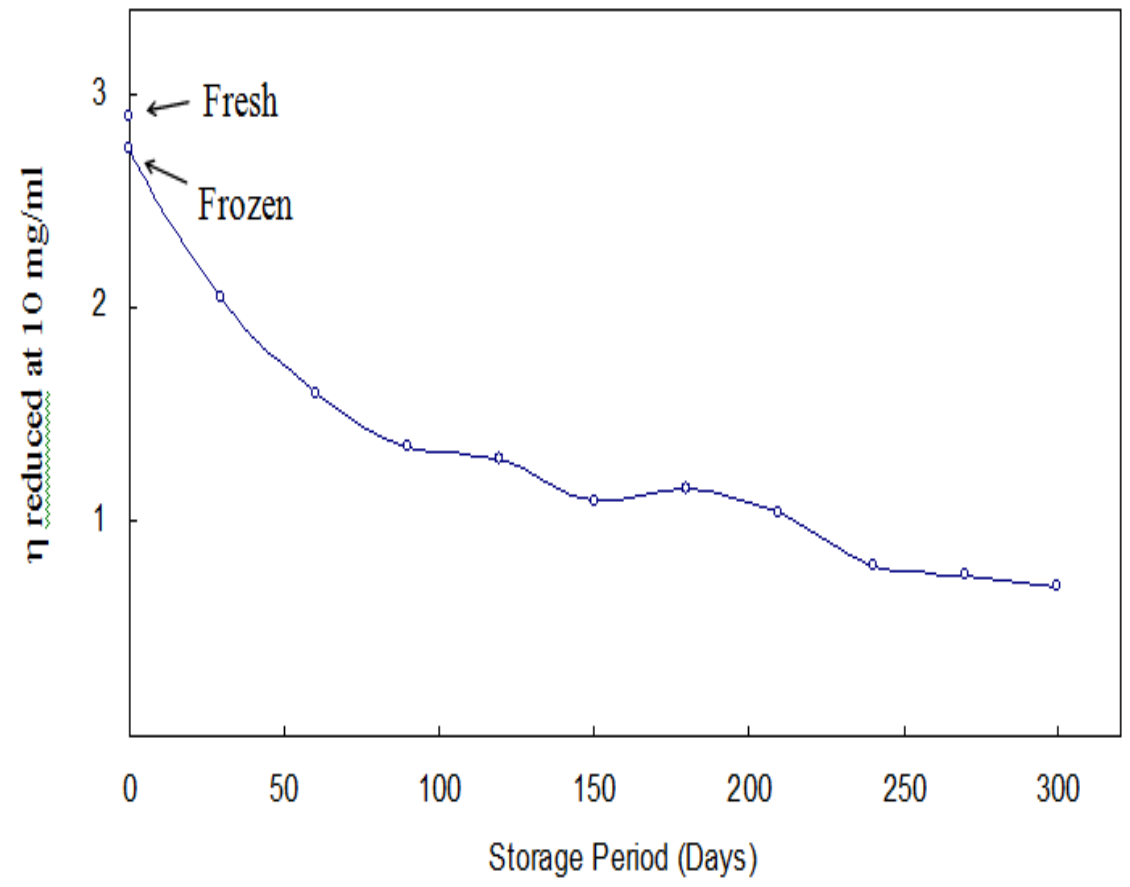

Apparent reduced viscosity of Total Protein form meat at $10 \mathrm{mg} / \mathrm{ml}$ protein concentration as a function of frozen storage period at $-20^{\circ} \mathrm{C}$ 
Fig.4 Changes in gelfiltration profile of total protein from pinkperch meat on sepharose $6 \mathrm{~B}$ gel, as a function of freezing and frozen storage at $-20^{\circ} \mathrm{C}$. The eluant used was extraction buffer (phosphate buffer, 50mM, pH 7.5; containing $1 \mathrm{M} \mathrm{NaCl}$ )

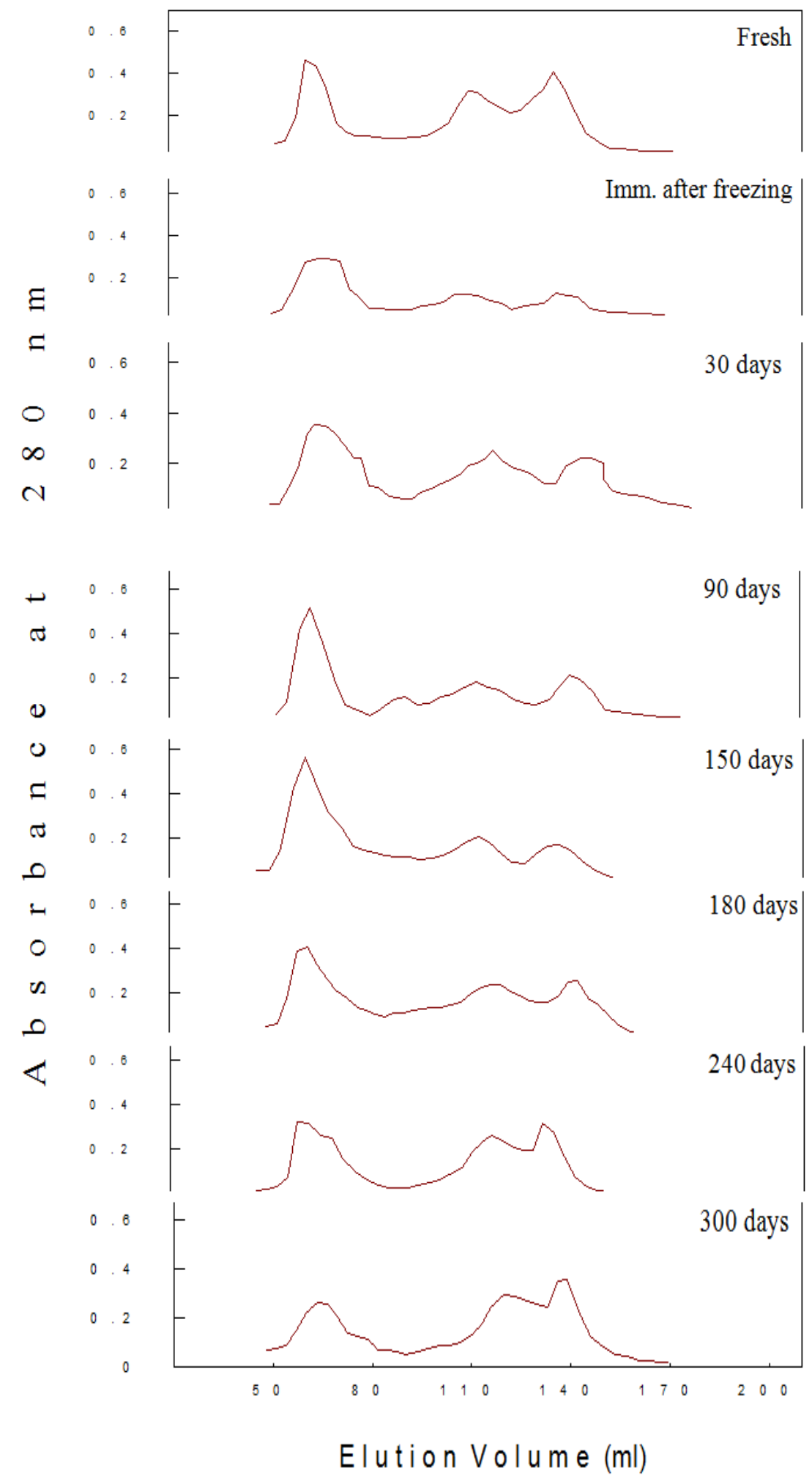


Fig.5 Changes in sol-gel transition (tan $\square$ ) during dynamic viscoelastic measurement of pinkperch meat as a function of freezing and frozen storage at $-20^{\circ} \mathrm{C}$. A) fresh pinkperch B) immediately after freezing C) 30 days D) 90 days E) 120 days F) 150 days G) 240 days H) 300 days
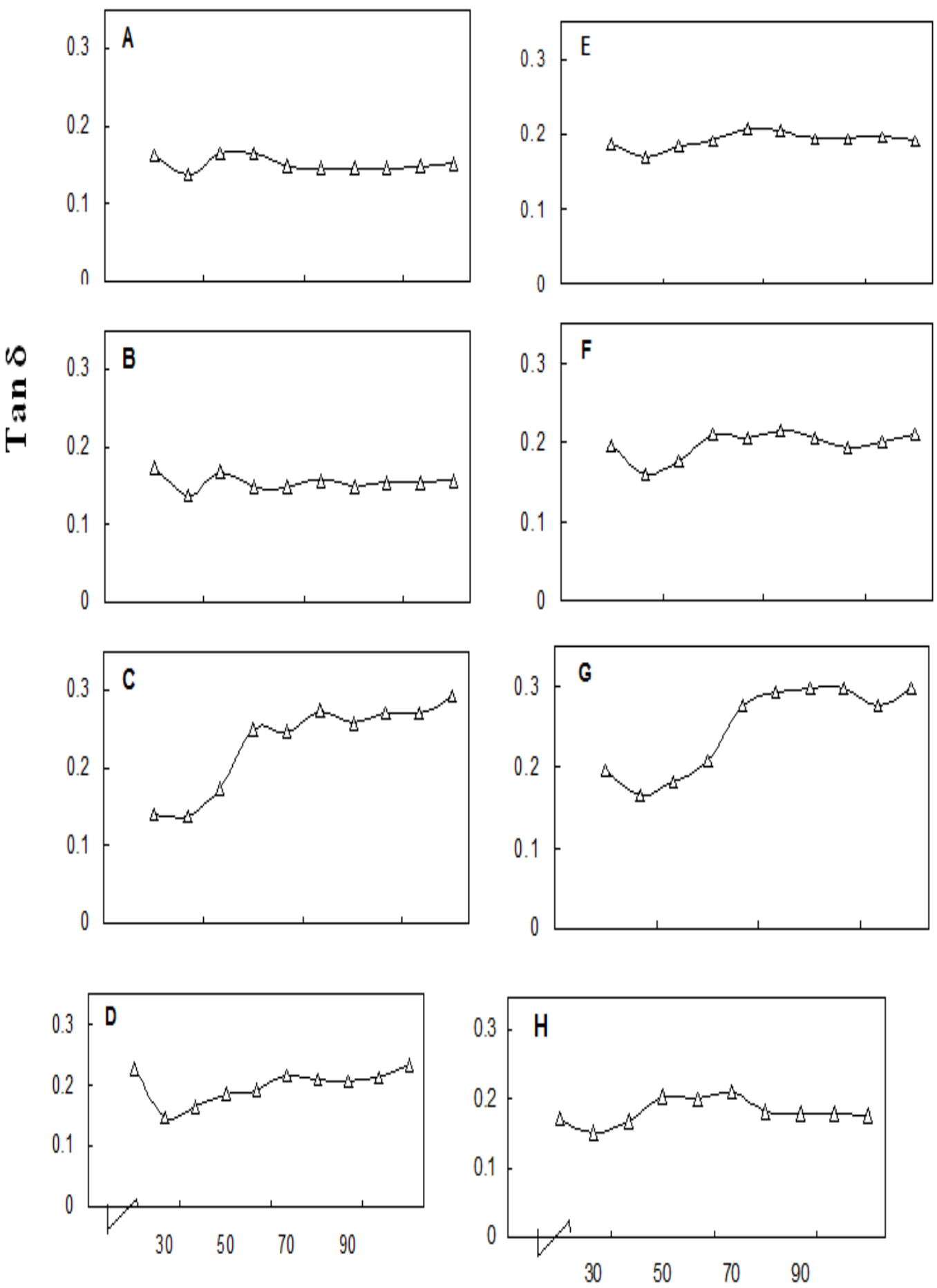

Temperature $\left({ }^{\circ} \mathrm{C}\right)$ 
Fig.6 Changes in sol-gel transition (tan $\square$ ) of set pinkperch meat during dynamic viscoelastic measurement as a function of freezing and frozen storage at $-20^{\circ} \mathrm{C}$. The meat set at $30^{\circ} \mathrm{C}$ for 1 hr. A) fresh pinkperch B) immediately after freezing C) 30 days D) 90 days E) 120 days F) 150 days $G) 240$ days $H$ ) 300 days
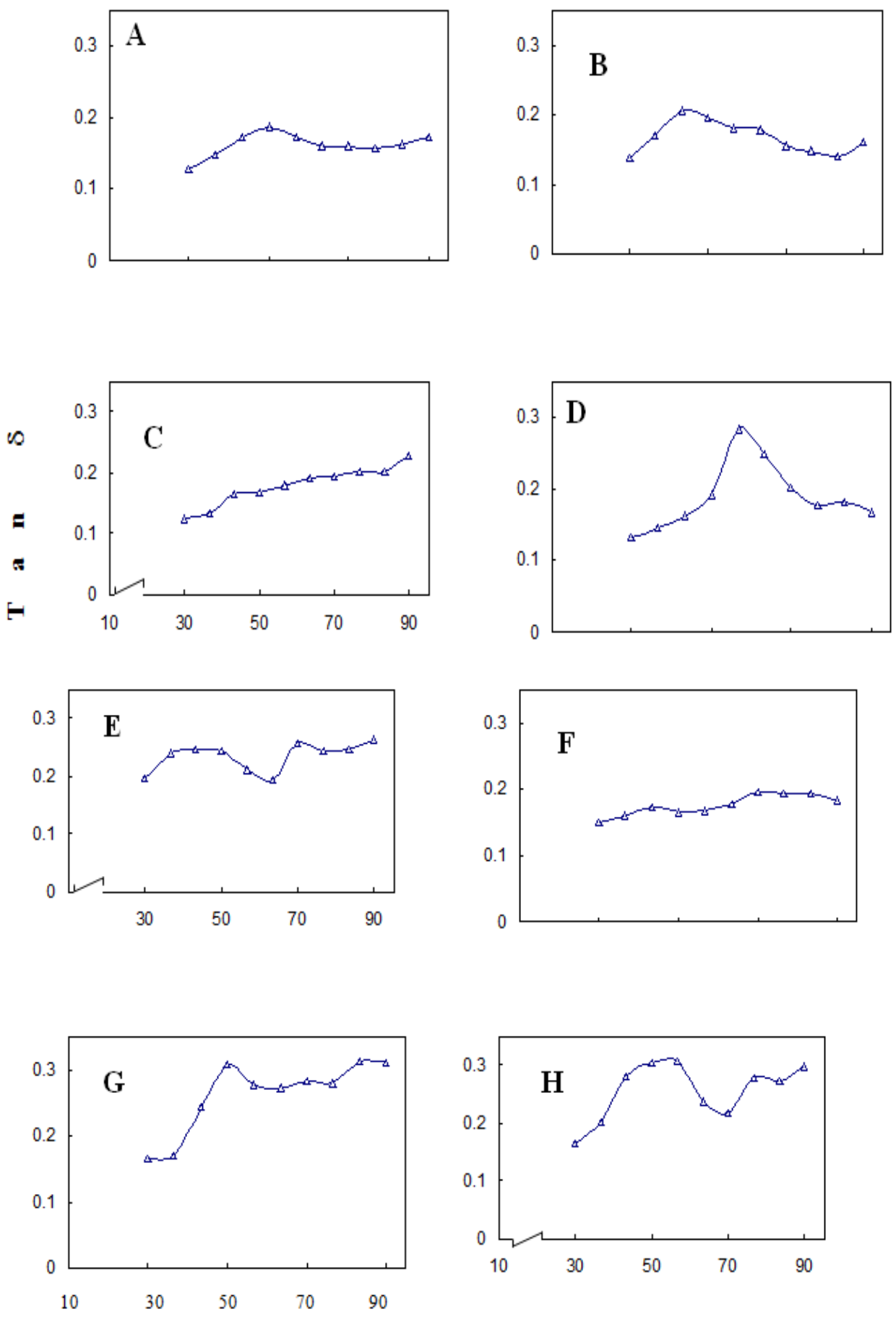

T e m p e r a t u re $\left({ }^{\circ} \mathrm{C}\right)$ 
Fig.S1 Changes in EC\&ES of total proteins from pink perch meat as a function of freezing and frozen storage at $-20^{\circ} \mathrm{C}$

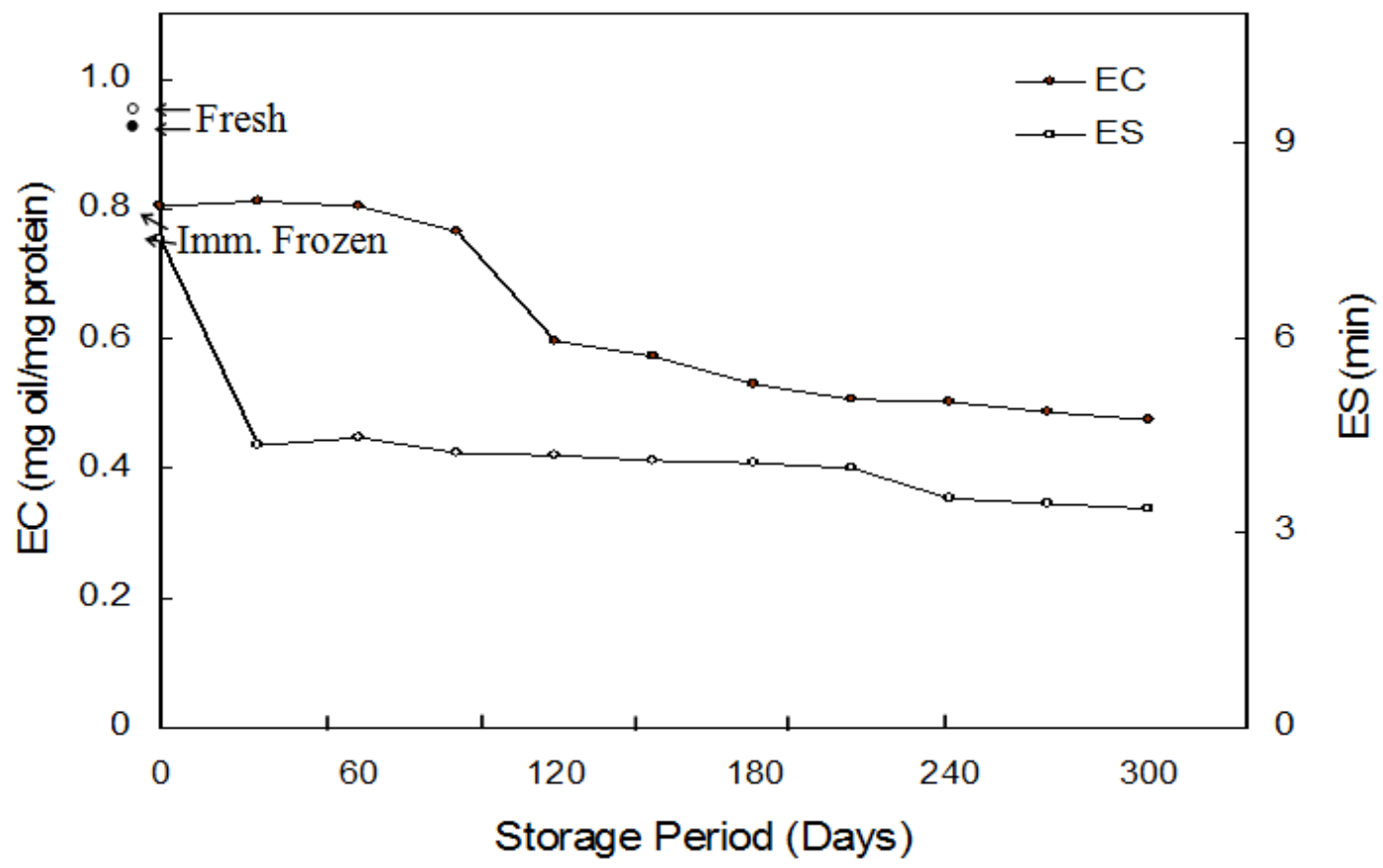

Fig.S2 Changes in gel strength of set and unset meat of pinkperch as a function of freezing and frozen storage at $-20^{\circ} \mathrm{C}$

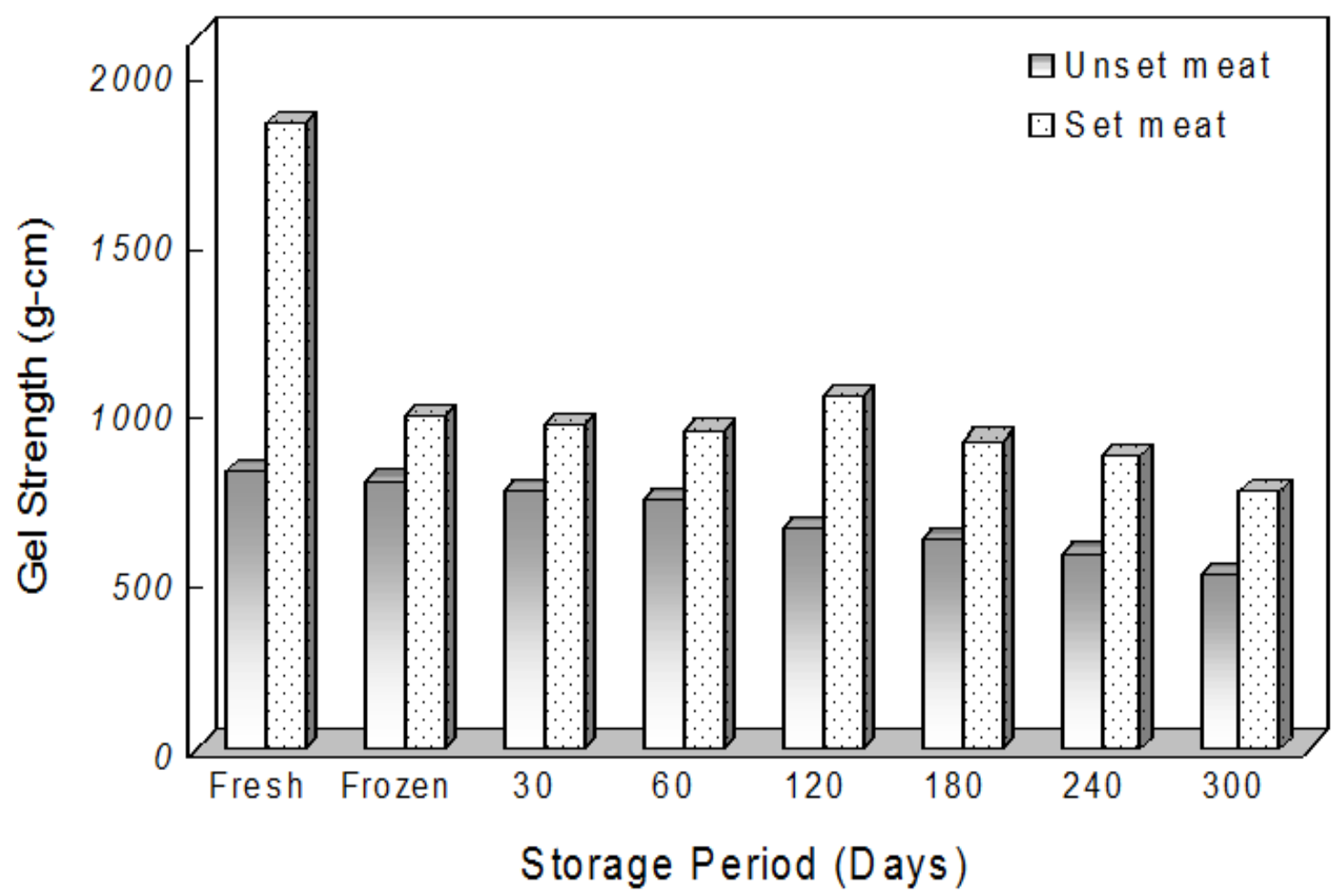


Fig.S3 Changes in dynamic viscoelastic behaviour of pinkperch meat in the temperature range of $30-90^{\circ} \mathrm{C}$, as affected by freezing and frozen storage at $-20^{\circ} \mathrm{C}$. DVB was carried out under oscillatory mode. A) fresh pinkperch B) immediately after freezing C) 30 days D) 90 days E) 120 days F) 150 days $G) 240$ days H) 300 days
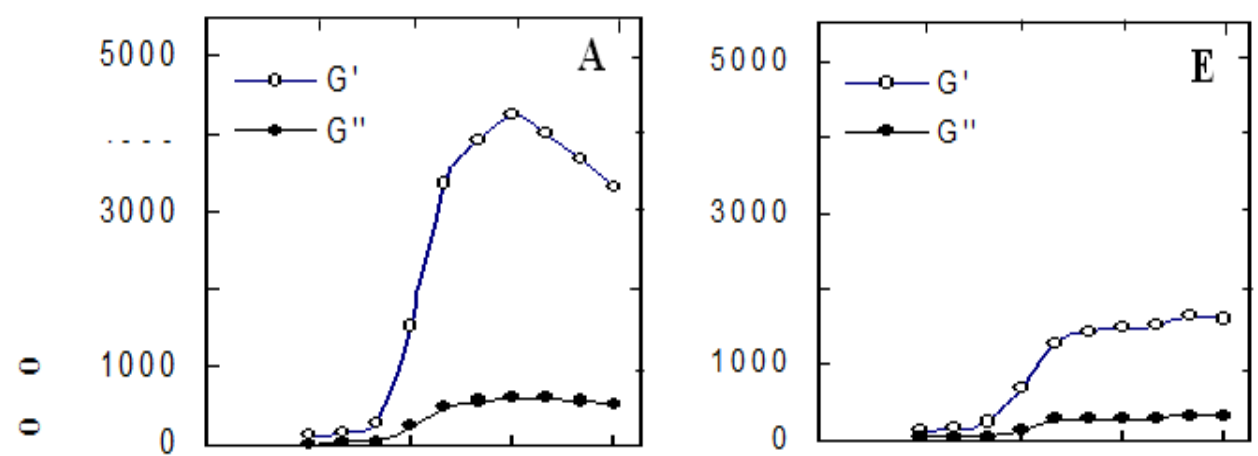

$\theta$
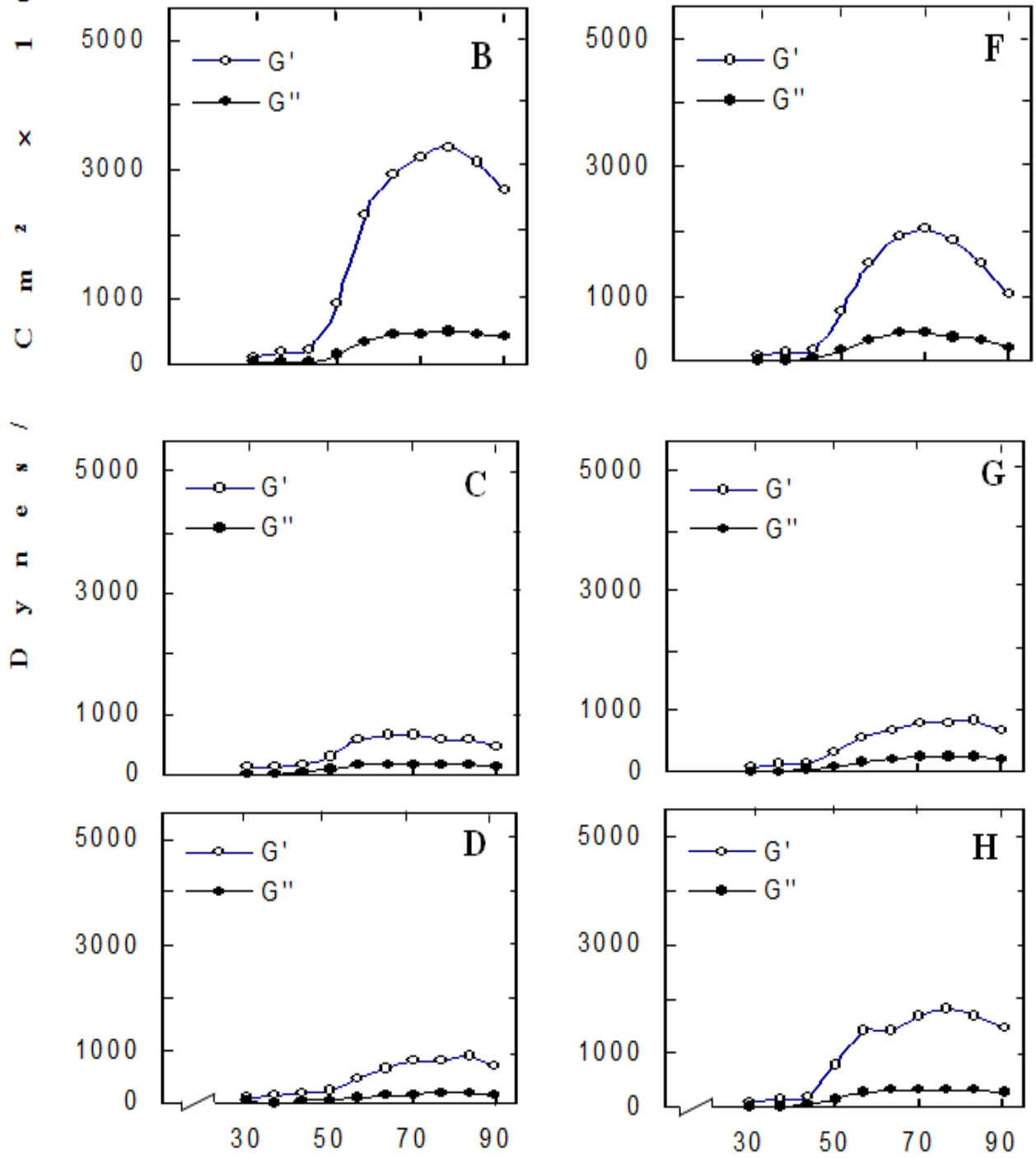

T e mperature $\left({ }^{\circ} \mathrm{C}\right)$ 
Fig.S4 Changes in the dynamic viscoelastic behaviour of set pinkperch meat, in the temperature range of $30-90^{\circ} \mathrm{C}$ as a function of freezing and frozen storage at $-20^{\circ} \mathrm{C}$. The meat set at $30^{\circ} \mathrm{C}$ for

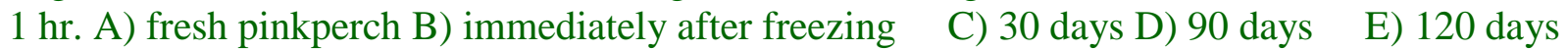
F) 210 days
G)240 days
H) 300 days

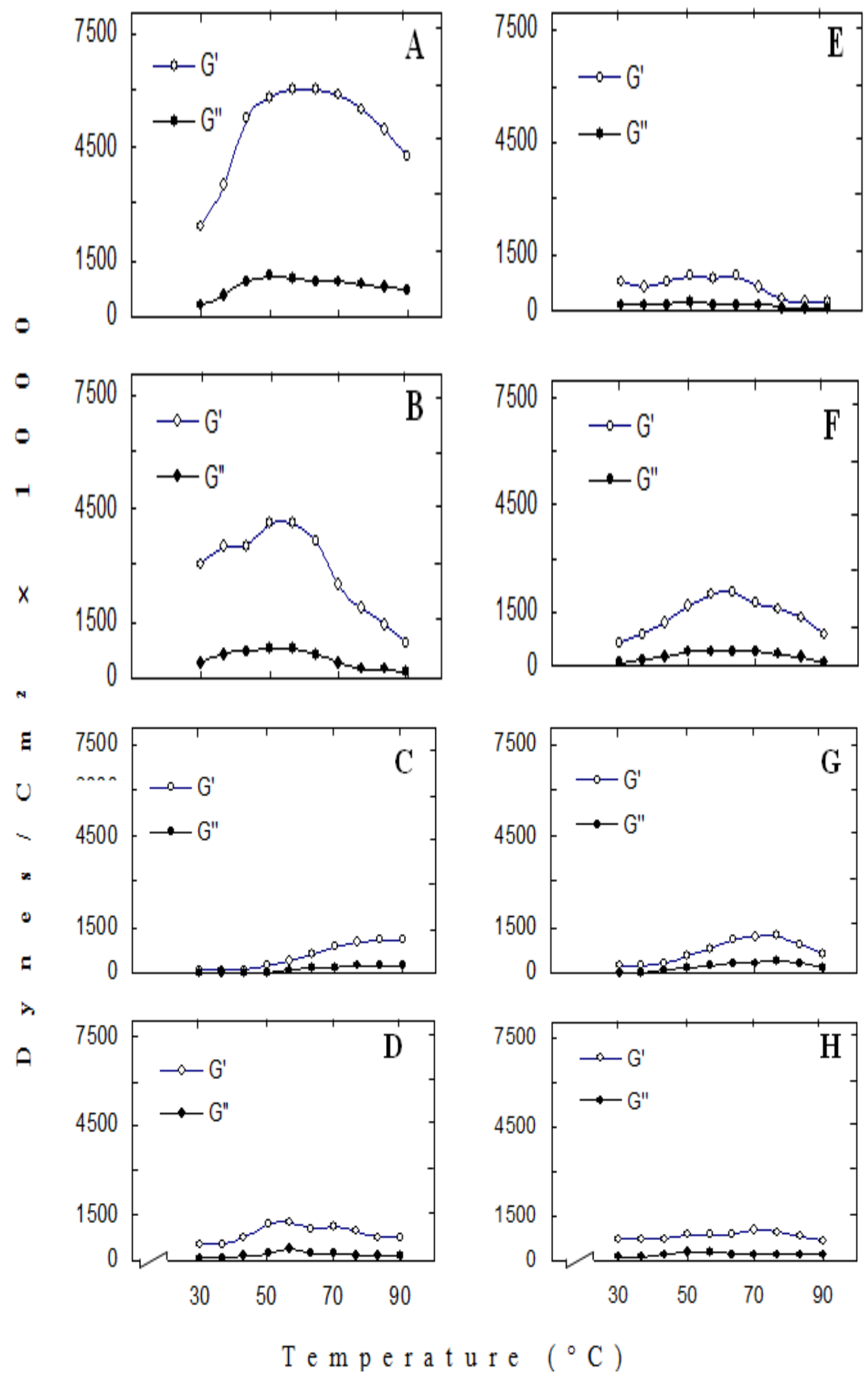


Table.1 Physico-chemical and functional properties of protein from fresh pinkperch meat

\begin{tabular}{|c|c|}
\hline Moisture \% & $73.84( \pm 0.28)$ \\
\hline Protein $\%$ & $18.90( \pm 0.33)$ \\
\hline Fat $\%$ & $2.98( \pm 0.18)$ \\
\hline Ash \% & $4.28( \pm 0.02)$ \\
\hline NPN (mg/100 $\mathrm{g}$ of meat) & $298.7( \pm 0.18)$ \\
\hline Solubility in EB (\% total protein) & $91.2( \pm 0.34)$ \\
\hline $\begin{array}{l}\mathrm{Ca}^{++} \text {ATPase activity } \\
\quad(\mu \mathrm{g} \mathrm{Pi} / \mathrm{mg} \text { protein/min })\end{array}$ & $0.684( \pm 0.08)$ \\
\hline Reduced viscosity at $10 \mathrm{mg} / \mathrm{ml}$ & 2.9 \\
\hline $\begin{array}{l}\text { Water absorption capacity } \\
\text { (g water/g dried material) }\end{array}$ & $3.7( \pm 0.447)$ \\
\hline Emulsion capacity (ml oil/mg protein) & $0.811( \pm 0.45)$ \\
\hline Emulsion stability (min) & 9.56 \\
\hline $\begin{array}{l}\text { Gel strength g.cm } \\
\text { Unset meat } \\
\text { Set meat }\end{array}$ & $\begin{array}{l}820.5( \pm 2.13) \\
1844.13( \pm 4.56)\end{array}$ \\
\hline
\end{tabular}

Table.2 Changes in water absorption capacity of pink perch meat as a effects of freezing and frozen storage

\begin{tabular}{|l|c|}
\hline Age of Fish (days) & $\begin{array}{c}\text { Water absorption capacity } \\
\text { (g water/g dried material) }\end{array}$ \\
\hline Fresh & 3.70 \\
\hline Immediately after freezing & 3.56 \\
\hline 30 & 3.46 \\
\hline 60 & 3.17 \\
\hline 150 & 2.89 \\
\hline 300 & 2.78 \\
\hline
\end{tabular}

Table.3 Correlation matrix of results of physico-chemical tests on whole pinkperch stored at $20^{\circ} \mathrm{C}$ for 10 months

\begin{tabular}{|l|r|r|r|r|}
\multicolumn{1}{|c|}{ Parameters } & Storage time & Extractability & $\begin{array}{c}\mathrm{Ca}^{2+} \text { ATPase } \\
\text { activity }\end{array}$ & Viscosity \\
\hline Extractability & $0.9324^{\mathrm{a}}$ & & & \\
\hline $\mathrm{Ca}^{2+}$ ATPase activity & $0.9046^{\mathrm{a}}$ & $0.8673^{\mathrm{a}}$ & & \\
\hline $\begin{array}{c}\text { Viscosity } \\
\text { Gel strength } \\
\text { set meat }\end{array}$ & $0.9497^{\mathrm{a}}$ & $0.8281^{\mathrm{a}}$ & $0.7923^{\mathrm{a}}$ & \\
\hline Unset meat & $0.78 .46^{\mathrm{a}}$ & $0.8329^{\mathrm{a}}$ & $0.7033^{\mathrm{a}}$ & 0.6056 \\
\hline
\end{tabular}

$\mathrm{a}=\mathrm{P}<0.05$ 
Table.4 The temperature at which maximum G' values recorded in set and unset meat

\begin{tabular}{|c|c|c|c|c|}
\hline \multirow{3}{*}{$\begin{array}{c}\text { Storage period } \\
\text { (days) }\end{array}$} & \multicolumn{4}{|c|}{$G^{\prime}$ maxima $\left(\right.$ dynes $\left./ \mathrm{cm}^{2} \times 1000\right)$} \\
\hline & \multicolumn{2}{|c|}{ Set } & \multicolumn{2}{|c|}{ Unset } \\
\hline & $\begin{array}{c}\text { Temperature } \\
{ }^{\circ} \mathrm{C}\end{array}$ & $G^{\prime}$ & $\begin{array}{l}\text { Temperature } \\
{ }^{\circ} \mathrm{C}\end{array}$ & $\mathrm{G}^{\prime}$ \\
\hline Fresh & 56.6 & 5984.0 & 70.0 & 4243.0 \\
\hline Immediately frozen & 56.6 & 4108.0 & 76.7 & 3366.0 \\
\hline 30 & 63.5 & 664.3 & 83.5 & 1079.0 \\
\hline 90 & 56.8 & 1305.0 & 83.3 & 872.0 \\
\hline 120 & 63.5 & 981.2 & 83.3 & 1618.0 \\
\hline 150 & 63.5 & 3219.0 & 70.0 & 2062.0 \\
\hline 210 & 63.3 & 2039.0 & 70.0 & 2437.0 \\
\hline 240 & 70.0 & 1131.0 & 83.3 & 837.2 \\
\hline 300 & 70.0 & 1037.0 & 76.7 & 1836.0 \\
\hline
\end{tabular}

Table.5 Temperature at which maximum rate of increase in G' value recorded in unset and set meat

\begin{tabular}{|c|c|c|c|}
\hline Sample (days) & Temperature range & Unset & Set \\
\hline Fresh & $43.3-50.0$ & 5.0 & 1.1 \\
\hline Imm. Frozen & $43.4-50.1$ & 4.19 & 1.2 \\
\hline 30 & $43.4-50.1$ & 2.02 & 1.93 \\
\hline 90 & $50.0-56.7$ & 1.89 & 1.62 \\
\hline 120 & $43.4-50.1$ & 2.95 & 1.17 \\
\hline 150 & $43.4-50.1$ & 4.70 & 2.0 \\
\hline 210 & $43.4-50.1$ & 3.24 & 1.4 \\
\hline 240 & $43.4-50.1$ & 2.23 & 1.7 \\
\hline 300 & $43.4-50.1$ & 4.02 & 1.2 \\
\hline
\end{tabular}

The denatured protein will not be able to reduce the interfacial tension between oil and water phase. However, in some of the protein system, the stability of the emulsion form will improve upon denaturation of protein molecule (Aoki et al., 1980).

The WAC of the fresh pinkperch meat was $3.7 \mathrm{~g}$ water $/ \mathrm{g}$ dried material. WAC value decreased to 2.55 at the end of 60 days of storage and a slight increase was observed after 300 days of storage (Table 2). The ability of the protein molecules to adsorb the added water will decrease with alteration of native structure (Hermansson, 1972). As the
WAC was estimated in the freeze-dried material the effect of freeze drying itself cannot be ruled out. The presence of other non-protein components in the meat may also influence the WAC.

The gel forming ability of pinkperch meat was evaluated by large strain test - Okado gellometer and small strain test - Controlled Stress Rheometer under Oscillatory mode in the temperature range of $30^{\circ} \mathrm{C}-90^{\circ} \mathrm{C}$. The strength of the gel obtained from the fresh unset pinkperch meat was $820 \mathrm{~g} \mathrm{~cm}$. The setting of pinkperch meat at $30^{\circ} \mathrm{C}$ for $1 \mathrm{hr}$ and further heat processing increased the gel 
strength by 2.2 fold (Table 1). The effect of freezing and frozen storage on the gel strength of the gel obtained from pinkperch fish (both unset and set) were given in Figure 8 . The progressive reduction in gel strength values of both set and unset values demonstrates the inability of myofibrillar proteins to orient itself for proper network formation. This is mainly due to loss in solubility (Fig. 2A) because of formation of insoluble aggregate. However, pinkperch meat could retain the setting ability even after 300 days of frozen storage as revealed by the gel strength values. There was a significant correlation between the frozen storage period and the gel strength values of set and unset meat (Table 3 ). The effect of freeze denaturation of protein from herring surimi (Chan et al., 1995) and on Alaska pollock surimi (Numakura et al., 1989) on the final gel quality revealed similar observation.

\section{Dynamic viscoelastic behaviour}

The gelation process in the given temperature range can be monitored continuously by small strain test using Controlled Stress Rheometer (CSR). In the present study the dynamic viscoelastic behaviour of pinkperch meat in the temperature range of $30^{\circ}-90^{\circ} \mathrm{C}$ was monitored. Figure 9A-H represents dynamic viscoelastic behaviour of unset pinkperch meat as a function of frozen storage period. The fresh pinkperch meat showed a structure build up reaction between $50^{\circ}-70^{\circ} \mathrm{C}$, due to increase in elastic component as revealed by storage modulus $\left(G^{\prime}\right)$ values. The maximum $G^{\prime}$ value was observed at $70.1^{\circ} \mathrm{C}$ and there after a decrease in value was observed. The building up of elastic component in the temperature range of 50 to $70^{\circ} \mathrm{C}$ is mainly due to hydrophobic interaction and disulfide bonds (Chan et al., 1992; Niwa et al., 1992). The addition of salt to the fish mince and grinding will establish a sol state and further heating will give rise to gel state, which has well defined three dimensional network. The temperature at which transition occur from sol to gel state can be obtained by measuring tan $\delta$ values which is a ratio of G'/G'. The sol gel transition of fresh unset pinkperch meat occurred at 2 temperature viz. $36.7^{\circ} \mathrm{C}$ and $50^{\circ} \mathrm{C}$ (Fig. 10A). The storage modulus (G') values decreased with increase in storage period upto 90 days of storage (Fig. 9A-D). There was a slight increase in the G'values in the samples stored at 120, 150 and 300 days in comparison to samples stored for 90 days. However, there was drastic reduction in the $G$ ' values at any given temperature from fresh to 300 days of storage. It is not clear as to how the storage modulus values could increase in samples stored for 120, 150 and 300 days. The storage modulus (G') values decreased at any given temperature with increase in frozen storage period. The failure to build up the elastic component during heating can be attributed to the inability of the molecules to form network. This inability could arise because of aggregation, that had occurred during frozen storage (Wu et al., 1985). The temperature at which the sol-gel transition occurred was unaltered during the initial storage period (Fig. 10A-C). There was no shift in the first transition temperature $\left(36.7^{\circ} \mathrm{C}\right)$ as a function of frozen storage period. It was found that there was a slight shift in the second transition temperature to $70-77^{\circ} \mathrm{C}$ in the later part of the storage period (Fig. $10 \mathrm{G}-\mathrm{H}$ ). This indicates frozen storage had a effect on gelling process of pinkperch meat. This was also confirmed by large strain test conducted by Okado gellometer.

The dynamic viscoelastic behaviour of the set pinkperch meat in the temperature range of $30^{\circ}-90^{\circ} \mathrm{C}$ is given in the Figure $11 \mathrm{~A}-\mathrm{H}$. The absolute $\mathrm{G}^{\prime}$ value of the set meat had a higher reading between 50 and $70^{\circ} \mathrm{C}$ compared to the unset meat. The frozen storage period significantly altered the structure build up 
reaction $\left(G^{\prime}\right)$ of set pinkperch meat. The temperature at which maximum $G^{\prime}$ value was obtained both in unset and set at $30^{\circ} \mathrm{C}$ for $1 \mathrm{hr}$ is given in Table 4. The higher $G^{\prime}$ values could be achieved in set meat at a lower temperature than in that of unset meat. For instance in fresh condition, the maximum $\mathrm{G}^{\text {' }}$ values was achieved at $56.6^{\circ}$ and at $70^{\circ} \mathrm{C}$ in the set and unset meat respectively. The frozen storage period did have influence on the ability to achieve elastic component in set meat also. The temperature at which maximum $G$ ' values were obtained increased with increase in frozen storage period. This result was observed both in set and unset meat.

The temperature at which maximum rate of increase in $G$ ' values of unset and set meat as a function of frozen storage period is given in Table 5. It was found that the maximum rate of increase in $G^{\prime}$ value was observed in the temperature range of $43^{\circ}-50^{\circ} \mathrm{C}$. Though gelling ability has been altered by freezing and frozen storage the rate of structure built up was constant at the temperature range of $43^{\circ}-50^{\circ} \mathrm{C}$. Comparatively the rate of structure built up was maximum in unset meat. This could be partly due to the nature of interaction that had occurred during setting process. However, the absolute $G$ ' values were higher in case of set meat. During the cooking of unset sol, a different gel structure could results due to the rapid unfolding of proteins forming hydrophobic and disulfide bonds (Tejada, 1994).

The sol-gel transition in fresh set meat occurred at $50.1^{\circ} \mathrm{C}$ (Fig. 12A). The temperature at which the sol-gel transition occurs did not follow any particular pattern with reference to frozen storage period. However, the setting experiments carried out from meat stored at different period occurred between 43.0 and $83.0^{\circ} \mathrm{C}$ being first and second transition (Fig. $12 \mathrm{~A}-\mathrm{H}$ ).
The freezing and frozen storage of whole pinkperch meat for a period of 300 days revealed an aggregation process of proteins as indicated by the protein solubility, reduction in ATPase enzyme activity, decrease in apparent reduced viscosity $(10 \mathrm{mg} / \mathrm{ml}$ protein concentration), gel filtration profile and SDSPAGE pattern. This aggregation process altered surface active property and gel forming ability. The gellation profile revealed the structure build up reaction was decreased with increase in frozen storage period. The setting of pinkperch meat at $30^{\circ} \mathrm{C}$ for $1 \mathrm{hr}$ could increase the final strength of the gel.

\section{References}

AOAC, 1984. Official method of Analysis, $13^{\text {th }}$ edition (W. Horowtiz, Ed.). Association of Official Analytical Chemists, Washington DC.

Aoki, H. Taneyama, O. and Orimo, N. 1980. Emulsifying properties of soy protein: Characteristics of $7 \mathrm{~S}$ and $11 \mathrm{~S}$ proteins. J. Food Sci. 45, 534-538.

Asghar, A., Samejima, A. and Yasui. T. 1985. Functionality of muscle protein in gelation mechanisms of structured meat products CRC Crit. Rev. Food Sci. Nutr. 22, 27.

Borderias, A.J., Colmenero, J.F. and Tejada, M. 1985. Viscosity and emulsifying of fish and chicken muscle protein. J. Food Technol. 20, 31-42.

Bradbury, J.H. 1970. Viscosity. In: Physical principles and techniques in protein chemistry, Part B (S.J. Leach, Ed.). pp 99-145, Academic Press, New York.

Briskey, E.J. and Fukazawa, T. 1971. Myofibrillar proteins of skeletal muscle. In Advances in Food Research (C.O. Chichester, E.M. Mark, G.F. Stewart, eds.) pp. 273-349. Academic press, New York.

Chan, J.K. Gill, T.A. and Paulson, A.T. 1992. Cross-linking ability of myosin heavy 
chains from cod, herring and silver lake during thermal setting, J. Food Sci. 57, 906-912.

Chan, J.K., Gill, T.A., Thompson, J.N. and Singer, D.S. 1995. Herring surimi during low temperature setting, physico chemical and textural properties. J. Food Sci. 60, 1248-1253.

CMFRI, 1995. Marine Fisheries Information service, 136 pp. 3-18, CMFRI, Cochin, India.

Colemenero, F.J. and Borderias, A.. 1983. A study of effects of frozen storage on certain functional properties of meat and fish protein. J. Food Technol. 18, 731-737.

Damodaran, S. 1994. Structure - function relationship of food proteins. In protein functionality in food systems (N.S. Hettiarachchy, and G.R. Ziegler, eds.) pp. 1-38. IFT basic symposium series, 9. Marcel Dekker Inc. New York.

Foedgeding, E.A. 1987. Functional properties of turkey salt - soluble proteins. J. Food Sci. 52, 1495-1499.

Gopakumar, K. 1992. Indian food fishes. Biochemical composition, CIFT Publication, CIFT - Cochin. p. 28.

Hamann, D.D. 1992. Rheological studies of fish proteins. In international conference and Industrial exhibition on food hydrocolloids. Tsukuba, Japan, Nov, 16-20. pp. 4-49.

Hermansson, A. 1979. Aggregation and denaturation involved in gel formation. In. Functionality and protein structure. (A. Pour-el ed.) p 81, American chemical society, washington.

Hermansson, A.M. 1972. Functional properties of proteins for foods. Labens smith - Wiss Technol. 5, 24.

Holmes, K.L. Noguchi, S.F. and Mac Donald, G.A. 1992. The Alaska pollack resource and other species used for surimi. In surimi technology (T.C. Lanier and
C.M. Lee, eds) pp. 41-75. Marcel Dekker Inc. New York.

Kinsella, J.E. 1982. Relation between structural and functional properties of food protein. In: Food proteins (R.F. Fox, and J.J. Condon, eds.) pp. 51-103, Applied science publishers, New York.

Kinsella, J.E. 1984. Functional properties in food proteins. Thermal modification involving denaturation and gelation. In. Research in Food Science and nutrition (J. McLonghlin, ed.) p. 226, Book press, Dublin.

Laemmlli, U.K. 1970. Cleavage of structural protein during assembly of the head bacteriophage $\mathrm{T}_{4}$. Nature (London). 227, 680-685.

Mac Donald, G.A. and Lanier, T.C. 1991. Carbohydrates as cryoprotectants for meats and surimi. Food Technol. 45, 150-159.

Matsumoto, J.J. 1979. Denaturation of muscle proteins during frozen storage. In proteins at low temperature (O. Fennema, ed.) pp. 205-224. ACS symposium series 180, ACS, washington, DC.

Matsumoto, J.J. 1980. Chemical deterioration of fish muscle proteins during frozen storage. In. Chemical deterioration of protein. (J.R. Whitaker, and M. Fujimaki, eds.) pp. 95-124. American Chemical Society, Washington DC.

Montecchia, C.L., Roura, S.I., Roladan, H., Perejborla, O. and Crupkin, M. 1997. Biochemical and physico-chemical properties of actomyosin from frozen pre-and post-spawned hake. J. Food Sci., 62, 491-495.

Montejano, J.G., Hamann, D.D. and Lanier, T.C. 1985. Comparison of two instrumental methods with senssory texture of protein gels. J. Texture stud. $16,403$.

Niwa, E. 1992. Chemistry of surimi gelation. In surimi technology (T.C. Lanier, and 
C.M. Lee, eds) p. 389. Marcel Dekker Inc. New York.

Noguchi, S. and Matsumoto, J.J. 1970. Studies on the control of denaturation of the fish muscle proteins during the frozen storage 1. Preventive effect of Na-glutamase. Bull. Jap. Soc. Sci. Fish., 36, 1078-1087.

Numakura, T., Mizoguchi, R., Kimura, I., Toyoda, K., Fujita, T., Seki, N. and Arai, K. 1989. Changes in gel forming ability and croos-linking ability of myosin chain of Alaska pollack surimi denatured by heat treatment. Nippon suisan Gakkaishi, 55, 1083-1090.

Ohnishi, M. and Rodger, G.M. 1980. Analysis of the salt soluble protein fraction of cod muscle by gel filtration. In Advances in Fish Science and Technology. (J. J. Connell, ed.) pp. 420428, Fishing News Books Ltd., Surrey, U.K.

Pastoriza, L., Sampedro, G. and Herera, J.J. 1994. Effects of mincing and frozen storage on functional properties of Ray muscle (Raja clavata). J. Sci. Food Agric. 66, 35-44.

Paulson, A.T. and Tung, M.A. 1988. Emulsification properties of succinglated Gnome protein isolate. J. Food Sci., 53, 817-820.

Reddy, G.V.S. and Srikar, L.N. 1991. Preprocessing ice storage effects on functional properties of fish mince protein. J. Food Sci. 56, 965-968.

Seki, N. and Arai, K. 1974. Gel filtration and electrophoresis of fish myofibrillar proteins in the presence of sodium dodecyle sulphate. Bull. Jap. Soc. Sci. Fish. 40, 1187-1194.

Sen, D.P. and Revanker, G.D. 1972. Seasonal variation in the amount of oil of oil sardine fish. J. Food Sci. Tech. 9, 93.

Shamasundar, B.A. and Prakash, V. 1994a. Physico-chemical and functional properties of protein from prawns
(Metapenacus dobsoni). J. Agric. Food Chem. 42, 169-174.

Shenouda, S.Y.K. 1980. Theories of protein denaturation during frozen storage of fish flesh. Adv. Food Res., 26, 275-311.

Sikorski, Z., Olley, J. and Kostuch, S. 1976. Protein changes in frozen fish. Crit. Rev. Food Sci. Nutr. 8, 97.

Sousulski, F.W. 1962. The centrifuge method for determining water absorption in hard red spring wheats. Cereal che., 39, 344-350.

Srikar, L.N. and Reddy, G.V.S. 1991. Protein solubility and emulsifying capacity in frozen stored fish mince. J. Sci. Food Agric. 55, 447-453.

Suzuki. T. 1981. Frozen minced meat (surimi). In. Fish and krill protein processing Technology. pp. 115-147. Applied science publishers. London.

Swift, C.E., Lockett, C. and Fryer, A.J. 1961. Communated meat emissions the capacity of meats for emulsifying fat. Food Technol., 15, 468 .

Tarr, H.L.A. 1958. Biochemistry of fishes. Am. Rev. Biochem. 27, 223-224.

Taussky, H.H. and Shorr, E. 1952. A microcolorimetric method for the determination of inorganic phosphorus. J. Bio. Chem., 202, 675-685.

Tejada, M. 1994. Gelation of myofibrillar fish proteins. Rev. Esp. Cienc. Technol. Aliment. 34, 257-273.

Tsuchiya, Y., Tsuchiya, T. and Matsumoto, J.J. 1980. The nature of the cross-bridge constituting aggregates of frozen stored carp myosin and actomyosin. In Advances in Fish Sciences and Technology (J.J. Connell, ed.) pp. 434438, Fishing News (Books) Ltd. London.

Umemoto, S. and Kanna, K. 1970. Studies on gel filtration on fish muscle protein IV. Changes in elution patterns by gel filtration of extractable protein of fish and rabbit muscle during cold storage at 
$-20^{\circ}$ C. Bull. Jap. Soc. Sci. Fish. 36, 798-805.

Velankar, N.L. and Govindan, J.K. 1958. A preliminary study of the distribution of non-protein nitrogen in some marine fishes and invertebrates. Proc. Indian Acad. Sci., 47, 202-209.

Wu, M.C., Akahane, T., Lanier, T.C. and Hamann, D.D. 1985. Thermal transition of actomyosin and surimi prepared from Atlantic croaker as studied by differential scanning calorimetry. J. Food Sci. 50, 10-13.

Xiong, L.Y. 1997. Structure function relationships of muscle proteins. In Food proteins and their applications (S.
Damodaran, and A. Paraf, eds.) pp. 341386, Marcel Dekker. Inc. New York.

Xiong, Y.L. 1992. Thermally induced interactions and gelation of combined myofibrillar protein from white and red boiler muscles. J. Food Sci. 57, 581-585.

Yamane, T. 1967. Statistics, an introductory analysis. Harper and row (eds.) New York.

Yang, J.T. 1961. The viscosity of macromolecular relation to molecular conformation. Adv. Protein Chem., 16, $323-400$.

Ziegler, G.R. and Foregeding, A.E., 1990. The gelation of proteins. Adv. Food Nutr. Res. 34, 203-298.

\section{How to cite this article:}

Rathnakumar, K. 2018. Physico-Chemical, Functional and Rheological Properties of Proteins from Pinkperch (Nemipterus japonicus) Meat: Effect of Freezing and Frozen Storage. Int.J.Curr.Microbiol.App.Sci. 7(03): 3113-3135. doi: https://doi.org/10.20546/ijcmas.2018.703.361 